Hydraulic Engineering Repository

Ein Service der Bundesanstalt für Wasserbau

Musavi Jahromi, S. H.; Helalat Nasserian, $\mathrm{H}$.

Effect of Tailwater Depth on the Scour Downstream of Falling Jets

Verfügbar unter / Available at:

https://hdl.handle.net/20.500.11970/100279

Vorgeschlagene Zitierweise / Suggested citation:

Musavi Jahromi, S. H.; Helalat Nasserian, H. (2010): Effect of Tailwater Depth on the Scour Downstream of Falling Jets. In: Burns, Susan E.; Bhatia, Shobha K.; Avila, Catherine M. C.; Hunt, Beatrice E. (Hg.):

Proceedings 5th International Conference on Scour and Erosion (ICSE-5), November 7-10, 2010, San Francisco, USA. Reston, Va.: American Society of Civil Engineers. S. 688-696. 


\title{
Effect of Tailwater Depth on the Scour Downstream of Falling Jets
}

\author{
S. H. Musavi Jahromi ${ }^{1}$ and H. Helalat Nasserian ${ }^{2}$
}

\author{
${ }^{1}$ Associ. Prof., Faculty of Water Science Engineering, Shahid Chamran University, \\ Ahwaz, Iran, Ph.+98-611-3330635, email: habib@musavi.info \\ ${ }^{2}$ M.Sc in hydraulic Engineering, M.A.P.T. Consulting Engineers Firm, Tehran, Iran, \\ Ph.+98-916-3032706, email: honaserian@yahoo.com
}

\begin{abstract}
In this paper the results of an experimental study about effect of tailwater depth on the characteristics of local scour at downstream of falling jets is presented. A flume with $5 \mathrm{~m}$ length, $25 \mathrm{~cm}$ height and $10 \mathrm{~cm}$ width has been established. Jets with three shapes including; circular, square and rectangular are connected to the end of the flume. A Siliceous bed with $\mathrm{d}_{50}=1.27 \mathrm{~mm}$, three drop heights including; $35 \mathrm{~cm}$, $65 \mathrm{~cm}$ and $95 \mathrm{~cm}$ and three tailwater depth; $6 \mathrm{~cm}, 12 \mathrm{~cm}$ and $18 \mathrm{~cm}$ have been applied downstream of the jet. Different analysis of the observed data showed that the characteristics of scour-hole depend on erosion parameter, $\mathrm{F}_{0} /\left(\mathrm{H}_{\mathrm{c}} / \mathrm{R}_{\mathrm{H}}\right)$, and tailwater parameter, $T_{w} / R_{H}$. Also it is considered that increasing the tailwater depth from $6 \mathrm{~cm}$ to $12 \mathrm{~cm}$ and then to $18 \mathrm{~cm}$, at first causes increasing the depth, width and length of scour-hole and also the length of sediments mound on the average of 104, 42, 39 and $83 \%$, respectively, then causes decreasing these characteristics on the average of 23 , 24,18 and $16 \%$, respectively. In this case the height of sediments mound at downstream of scour-hole will increase on the average of $52 \%$. Finally, an equation as the scour characteristics predictor is proposed.
\end{abstract}

\section{INTRODUCTION}

Jets of water that impinge on the free surface due to the flow from an outlet situated above the free water surface are referred to as plunging jets. The overflow through openings of dam, flow from ski jump spillways and pipe outlets are some of the practical examples of plunging jets. The scour downstream of these hydraulic structures is of frequent occurrence and constitutes an important field of research. Moreover local scour can cause dam failure and endanger the safety of the dam. Due to the complex nature of these flows and their interaction with sediment beds, research on the erosion by jets has been mainly empirical. Abida and Townsend (1991) accomplished a study that investigated the local scouring phenomenon in sand bed downstream of model box culvert outlets. Maximum depth of local scour was found to vary with the tailwater depth. But, in this experiment the lying culvert on the bed with no drop height was applied. Nasehi (1996) performed a study in order to consider local scour at downstream of vertical drops. On the basis of experimental results, scour depth has direct relation with discharge and vice versa relation with tailwater depth. Also mounds are forming at downstream of scour-hole which their height and location depend on tailwater depth and flow discharge. Najafi and Ghodsian (2004) have done an experimental study on downstream scour of pipe culverts. Experimental results showed that increasing tailwater depth causes decreasing depth and width of scour-hole, but it causes increasing the scour-hole 
length, sediments mound height and scour-hole start point. Sarathi et al. (2005) accomplished a study on local scour due to 3D wall jets in non-cohesive sand beds. The results indicated that the tailwater has an effect on the scour geometry at lower tailwater conditions, however, at higher tailwater conditions, the effect was found to be minimized. Ghodsian et al. (2006) performed experiments on the scour due to impinging rectangular jet in uniform cohesive bed material. The results indicated that the depth of scour initially increases by increasing the tailwater depth and then decreases. In this paper, using dimensional analysis, a few dimensionless parameters have been established. A flume with several experimental instruments has been set up in the hydraulic laboratory of Shahid Chamran University, Ahwaz, Iran. The characteristics of the downstream scour and sediment mound due to the tailwater depth changes have been studied.

\section{MATERIALS AND PROCEDURES}

A schematic sketch of the experimental facilities is shown in figure 1. A flume with $5 \mathrm{~m}$ length, $25 \mathrm{~cm}$ height and $10 \mathrm{~cm}$ width has been established. Plexiglas jets with $30 \mathrm{~cm}$ length and three shapes including; circular, square and rectangular are connected to the end of the flume. A sediment tank with $2 \mathrm{~m}$ length, $1.5 \mathrm{~m}$ width and $0.75 \mathrm{~m}$ depth has been applied downstream of the jet. A slide gate is placed at the end of the sediment tank to regulate the tailwater depth. The height of the falling jets was set to be $35 \mathrm{~cm} ; 65 \mathrm{~cm}$ and $95 \mathrm{~cm}$. Characteristics of the jets are presented in Table 1 . In all tests, the silica with $\mathrm{d}_{50}=1.27 \mathrm{~mm}$ and unit weight $(\gamma)$ of $2.65 \mathrm{gr} / \mathrm{cm}^{3}$ was used as the downstream bed materials. The grain size distribution curve of the materials is shown in Figure 2. For measuring the characteristics of the scour-hole and its downstream sediments mound, a point gauge with accuracy range of $\pm 1 \mathrm{~mm}$ was used. It was placed on the rails and can be moved manually in longitudinal and transversal directions. In all tests, it was tried to maintain the water level behind the jets constant and equal to $15.5 \mathrm{~cm}$. The characteristics of the scour-hole and its downstream mound were measured after 31, 100 and 316 minutes, separately.

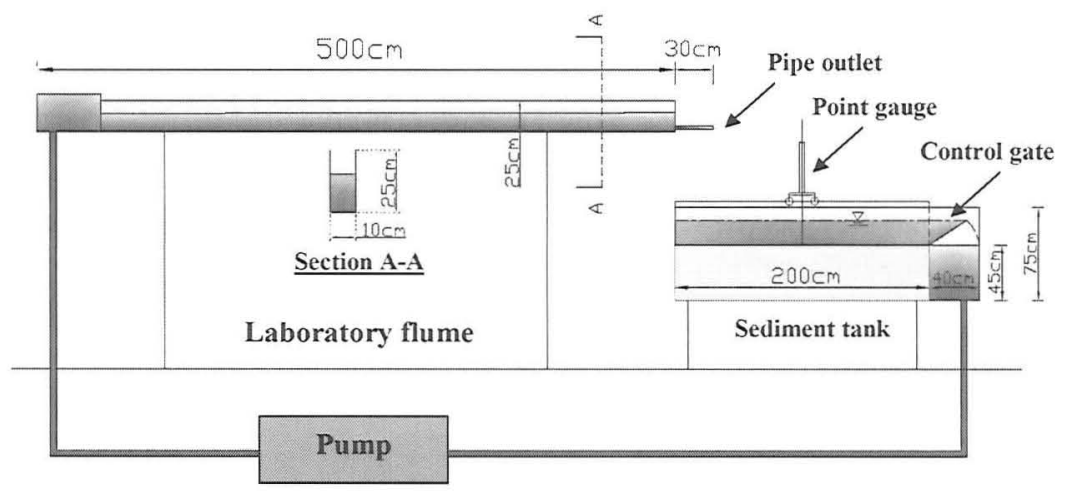

Figure 1. Longitudinal profile of laboratory flume and its attachments 
Table 1. Characteristics of falling jet

\begin{tabular}{c|c|c|c|c|c}
\hline Jet shape & $\begin{array}{c}\text { Cross-sectional } \\
\text { Area } \\
\left(\mathrm{m}^{2}\right)\end{array}$ & $\begin{array}{c}\text { Hydraulic Radius } \\
(\mathrm{m})\end{array}$ & $\begin{array}{c}\text { Width } \\
(\mathrm{m})\end{array}$ & $\begin{array}{c}\text { Height } \\
(\mathrm{m})\end{array}$ & $\begin{array}{c}\text { Discharge } \\
(\mathrm{l} / \mathrm{s})\end{array}$ \\
\hline Circular & 0.0007 & 0.0075 & 0.03 & 0.03 & 1.02 \\
\hline Square & 0.0009 & 0.0075 & 0.03 & 0.03 & 1.27 \\
\hline Rectangular & 0.0012 & 0.00857 & 0.04 & 0.03 & 1.77 \\
\hline
\end{tabular}

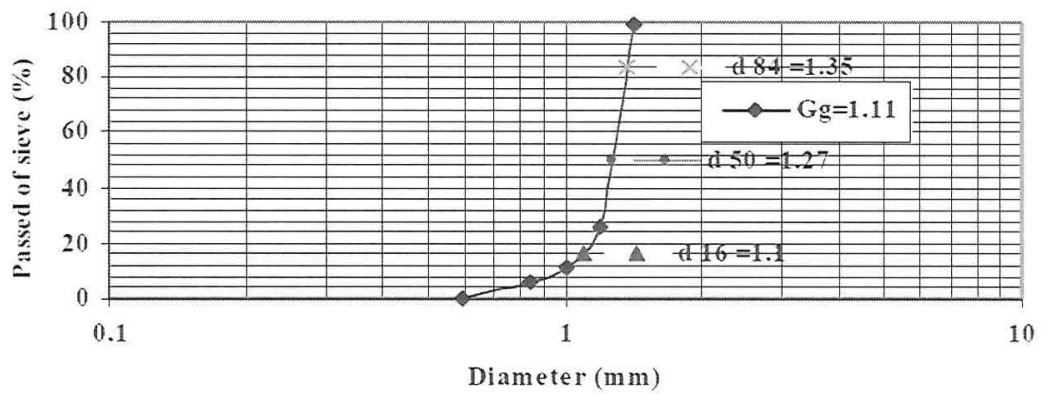

Figure 2. Grain size distribution curve

\section{DIMENSIONAL ANALYSIS} follows:

Scour processes downstream of a jet outlet depend on many variables as

1) The flow characteristics including discharge (Q), velocity at jet outlet (V), the tailwater depth $\left(T_{w}\right)$, the water density $(\rho)$, the dynamic viscosity of water $(\mu)$, the kinematic viscosity of water $(\mathrm{v})$, acceleration due to gravity $(\mathrm{g})$ and the water level behind the jet $(\mathrm{H})$.

2) The bed materials characteristic parameters: the effective particle size of the bed materials $\left(D_{s}\right)$, the density of the bed materials $\left(\rho_{s}\right)$, the geometric standard deviation of particle sizes $(\sigma)$, the fall velocity of sediments $(\omega)$, the angle of repose $(\varphi)$ and the shape factor $\left(\mathrm{S}_{\mathrm{f}}\right)$.

3) The jet characteristics: the height of jet location to the bed level $\left(\mathrm{H}_{\mathrm{c}}\right)$, the jet slope $(\mathrm{S})$, the jet length (L), the jet roughness coefficient (n), the shape of jet section (hydraulic radius) $\left(\mathrm{R}_{\mathrm{H}}\right)$, the jet section area $(\mathrm{A})$, and the entrance loss coefficient $(\mathrm{k})$. Finally time (t) and the sediment tank width (B) are two other parameters effecting the scour-hole conditions.

Thus, if $\Psi$ represents any dimensions of scour-hole and its downstream sediments mound, then:

$$
\psi=\mathrm{f}\left(\mathrm{Q}, \mathrm{V}, \mathrm{T}_{\mathrm{w}}, \rho, \mu, v, \mathrm{~g}, \mathrm{H}, \mathrm{D}_{\mathrm{s}}, \rho_{\mathrm{s}}, \sigma, \omega, \varphi, \mathrm{S}_{\mathrm{f}}, \mathrm{H}_{\mathrm{c}}, \mathrm{S}, \mathrm{L}, \mathrm{n}, \mathrm{R}_{\mathrm{H}}, \mathrm{A}, \mathrm{k}, \mathrm{t}, \mathrm{B}\right)
$$

However, for the purpose of this study some of these variables can be disregarded, and only the more significant ones are preserved. Q and $\mathrm{A}$ are eliminated since $V=Q / A$. $\mu$ and $v$ are eliminated since $\rho=\mu / v . \omega$ is eliminated since 
$\omega=\left(\rho_{\mathrm{s}}-\rho\right) \mathrm{gD}_{\mathrm{s}}{ }^{2} / 18 \mu$. The same bed material with uniform gradation was used for all experiments and thus $\varphi$ and $\mathrm{S}_{\mathrm{f}}$ and $\sigma$ were eliminated. $\mathrm{H}$ and $\mathrm{B}$ were considered to be constant in all experiments and therefore were disregarded. $\mathrm{S}=0$ since the pipe outlet was horizontal. $\mathrm{k}$ was not included because the study is limited to on type of pipe entrance. $\mathrm{L}$ is eliminated since the model pipe length is too short to affect the flow. The same pipe material was used for all experiments and thus $\mathrm{n}$ was eliminated in the analysis. $t$ was not included because we do not consider the scour-hole time changes in this study. Therefore, Eq. (1) can be simplified to:

$\psi=\mathrm{f}\left(\mathrm{V}, \mathrm{T}_{\mathrm{w}}, \rho, \mathrm{g}, \mathrm{d}_{50}, \Delta \rho, \mathrm{H}_{\mathrm{c}}, \mathrm{R}_{\mathrm{H}}\right)$

Upon performing dimensional analysis on Eq.(2), the following dimensionless term is obtained:

$$
\frac{\Psi}{R_{H}}=f\left(\frac{T_{w}}{R_{H}}, \frac{d_{50}}{R_{H}}, \frac{H_{C}}{R_{H}}, \frac{V}{\sqrt{g R_{H}}}, \frac{\Delta \rho}{\rho}\right)
$$

By rearranging Eq. (3), Eq. (4) is obtained:

$$
\frac{\Psi}{H_{C}}=f\left(\frac{T_{W}}{R_{H}}, \frac{F_{0}}{H_{c} / R_{H}}\right)
$$

In Eq. (4), $F_{0}$, is the densimetric Froude Number as follow:

$$
F_{0}=\frac{V}{\sqrt{g d_{50}(\Delta \rho / \rho)}}
$$

The scour characteristics measured in this experimental study were: the maximum scour-hole depth $\left(d_{s}\right)$, the maximum scour-hole length $\left(L_{s}\right)$, the maximum scour-hole width $\left(\mathrm{W}_{\mathrm{s}}\right)$, the maximum sediments mound height at the downstream of score hole $\left(\mathrm{h}_{\mathrm{m}}\right)$, the maximum sediments mound length at the downstream of score hole $\left(\mathrm{L}_{\mathrm{r}}\right)$, the horizontal distance of start point of scour-hole from jet outlet end $\left(\mathrm{L}_{\mathrm{up}}\right)$. Characteristics of scour-hole and its downstream sediments mound are shown in Figure 3.

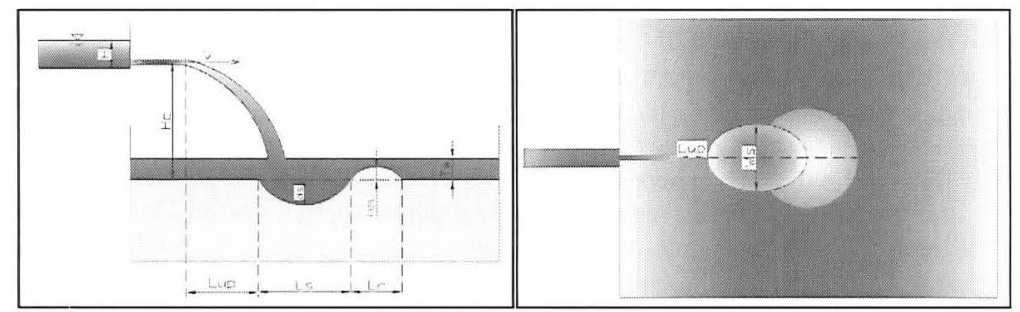

Figure 3. Schematic longitudinal profille and plan of the scour-hole 


\section{RESULTS AND DISCUSSION}

A total of 27 experiments on 3 jet shapes with 3 fall heights and 3 different tailwater depths were conducted. Related data of scour-hole and its downstream sediments mound characteristics were measured after 316 minutes run of the physical model. From the curve of scour dimensions changes to time was observed that the scour dimensions will reach to asymptotic state almost after 316 minutes.

\section{Observed Scour Profiles}

Initially, longitudinal and lateral scour profiles, in the location of maximum scour depth due to the tailwater depth were considered. The Influence of the tailwater depth on scour process for rectangular jet shape and drop height of $35 \mathrm{~cm}$ is shown in Figure 4. In this figure in the case of constant jet section and drop height, by increasing the tailwater depth from $6 \mathrm{~cm}$ to $12 \mathrm{~cm}$ and then $18 \mathrm{~cm}$, it is observed that:

1) The scour depth is increased from $10.5 \mathrm{~cm}$ to $16.7 \mathrm{~cm}$ and then will decrease to $13.2 \mathrm{~cm}$.

2) The distance of the location of maximum scour depth from jet end will increase from $43 \mathrm{~cm}$ to $53 \mathrm{~cm}$ and then to $57 \mathrm{~cm}$.

3) The scour width is increased from $45 \mathrm{~cm}$ to $56 \mathrm{~cm}$ and then will decrease to $45 \mathrm{~cm}$.

4) The scour length is increased from $48.5 \mathrm{~cm}$ to $61.5 \mathrm{~cm}$ and then will decrease to $53 \mathrm{~cm}$.

5) The sediments mound height will increase from $6 \mathrm{~cm}$ to $11.7 \mathrm{~cm}$ and then to $14 \mathrm{~cm}$.

6) The distance of the location of maximum sediments mound height from jet end is increased from $91 \mathrm{~cm}$ to $110 \mathrm{~cm}$ and then will decrease to $103 \mathrm{~cm}$.

7) The sediments mound length is increased from $30.5 \mathrm{~cm}$ to $42 \mathrm{~cm}$ and then will decrease to $41 \mathrm{~cm}$.

8) The distance of scour-hole start point from jet end remains approximately constant in $21 \mathrm{~cm}$, and then will increase to $26 \mathrm{~cm}$.

Similar figures obtained for other cases. Generally, by increasing the tailwater depth from $6 \mathrm{~cm}$ to $12 \mathrm{~cm}$ and then to $18 \mathrm{~cm}$, it is observed that:

1) Initially, the depth, width and length of scour-hole increase on the average of 104,42 and $39 \%$, respectively, and then will decrease 23,24 and $18 \%$, respectively.

2) The distance of the location of maximum scour-hole depth from jet end increases on the average of $7 \%$.

3) The tailwater depth has noticeable influence on sediments mound height at the downstream of scour-hole. By tailwater depth increasing, the shape and form of settled sediments at the downstream of scour-hole is different. While the tailwater depth is low, sediments will settle in uniform state (with a constant height) at downstream of scour-hole approximately, but for high tailwater depths, the settled sediments form a climax which has steep slopes at upstream and downstream. Because in higher tailwater depths, the released sediments will be moved easily by water flow and will settle where the flow turbulence due to jet impinging on the bed decrease. So they lose their energy near the water surface and form a climax at downstream of the scour-hole. Generally, the increasing of tailwater depth causes increasing downstream sediments mound height on the average of $52 \%$. 
4) The distance of the location of the maximum sediments mound height increase on the average of $30 \%$ and then will decrease $12 \%$.

5) The sediments mound length at the downstream of scour-hole initially increase on the average of $83 \%$, and then will decrease $16 \%$. Because in higher tailwater depths, climax formation will prevent the movement of released sediments to downstream. If these sediments have no enough energy to pass over the climax, they have to settle in the scour-hole. So that the sediments mound length will decrease.

6) Initially, the distance of scour-hole start point from jet end decrease on the average of $3 \%$ or remains constant and then will increase $20 \%$.

7) At $12 \mathrm{~cm}$ tailwater depth, maximum of scour characteristics are observed.

It also was observed that the movement manner and replacement of the released particles from the bed for various cases of the tailwater depth are different. In lower tailwater depths, released particles move vertically to the water surface, but after losing their kinetic energy a large amount of them will settle in the scour-hole again (ebullient manner). Whereas, in higher tailwater depths, impinging jet release particles and will move them to the downstream. So, no ebullient manner will be seen in the scour-hole.

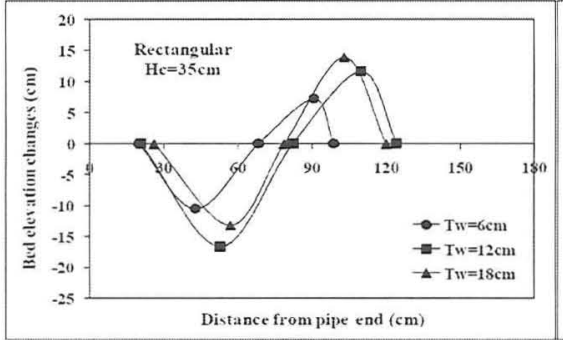

(a) Longitudinal profile

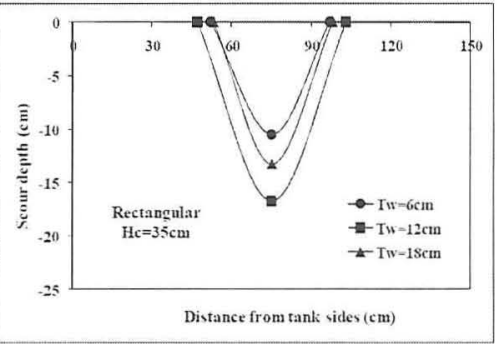

(b) Transversal profile

Figure 4. Rectangular jet's scour profiles for different tailwater depths (Drop height $=35 \mathrm{~cm}$ )

\section{Scour Characteristics Predictor}

The dimensionless parameters as determined from the dimensional analysis were evaluated to assess their influence on scour characteristics. For this purpose a plot was developed that showed the relation between the $\Psi / \mathrm{H}_{c}$ and the erosion parameter, $F_{0} /\left(H_{c} / R_{H}\right)$, for three different sizes of tailwater parameter, $T_{w} / R_{H}$. In Figure 5, a plot of the scour-hole length dimensionless parameter with respect to the erosion parameter is shown. Similar plots were developed for other scour-hole and its downstream sediments mound characteristics. A regression line for the best fit is drawn for each tailwater ratio. The best equation form for each tailwater ratio was the power form as; $y=a x^{b}$, Where $y$ is variable with $\Psi / H_{c}$ and $x$ is independent parameter of $F_{0} /\left(H_{c} / R_{H}\right)$, $a$ and $b$ are experimental constant parameters. Table 2 includes scourhole length ratio for different tailwater ratios. 


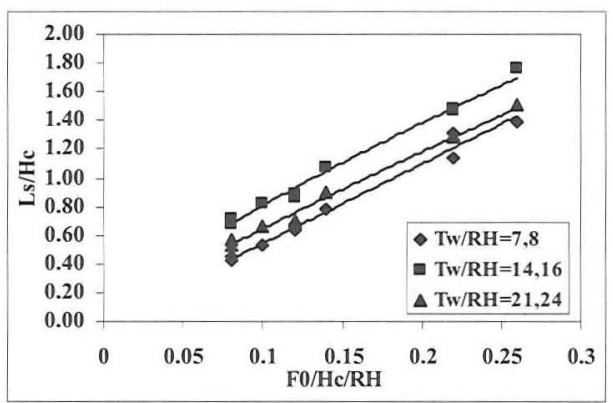

Figure 5. $\mathrm{L}_{\mathrm{s}} / \mathrm{H}_{\mathrm{c}}$ versus $\mathrm{F}_{0} /\left(\mathrm{H}_{\mathrm{c}} / \mathrm{R}_{\mathrm{H}}\right)$ for different tailwater ratios

Table 2. Equations coefficients for different tailwater ratios

\begin{tabular}{c|c|c|c|c}
\hline Scour characteristics & $\mathbf{T}_{\mathbf{w}} / \mathbf{R}_{\mathbf{H}}$ & $\mathbf{a}$ & $\mathbf{b}$ & $\mathbf{R}^{2}$ \\
\hline \multirow{3}{*}{$\mathbf{L}_{\mathbf{s}} / \mathbf{H}_{\mathbf{c}}$} & $\mathbf{7 , 8}$ & 5.615 & 1.015 & 0.989 \\
\cline { 2 - 5 } & $\mathbf{1 4 , 1 6}$ & 4.827 & 0.777 & 0.986 \\
\cline { 2 - 5 } & $\mathbf{2 1 , 2 4}$ & 4.817 & 0.874 & 0.982 \\
\hline
\end{tabular}

It is observed that with increasing of $F_{0} /\left(H_{c} / R_{H}\right)$ for different ratios of $T_{w} / R_{H}$, the parameter of $\Psi / \mathrm{H}_{\mathrm{c}}$ is increasing. Also it is found that for a constant value of $F_{0} /\left(H_{c} / R_{H}\right)$, the greatest values of $d_{s} / H_{c}, L_{s} / H_{c}, W_{s} / H_{c}$ and $L_{r} / H_{c}$ parameters occurred at $T_{w} / R_{H}=14,16$ and the greatest values of $h_{m} / H_{c}$ and $L_{u p} / H_{c}$ parameters occurred at $T_{w} / R_{H}=21,24$. In order to present a united equation for all ratios of $T_{w} / R_{H}$, a general form of the equation is as follows:

$$
\frac{\Psi}{H_{c}}=a\left(\frac{T_{w}}{R_{H}}\right)^{b}\left(\frac{F_{0}}{H_{c} / R_{H}}\right)^{c}
$$

The coefficient of $c$ can be a function of $T_{w} / R_{H}$. For evaluating the coefficient of $c$, four states of the function of $T_{w} / R_{H}$ must be taken into consideration (Table 3 ). To determine the best form of the coefficient of $\mathrm{c}$ to be assigned to equation 6 , the following equation can be used to minimize prediction error:

$$
E=\frac{100}{N} \sum_{i=1}^{N}\left|\frac{Y_{\text {observed }}-Y_{\text {computed }}}{Y_{\text {observed }}}\right|
$$

Where $\mathrm{E}$ is error term between observed and computed values, $\mathrm{Y}_{\mathrm{observed}}$ and $\mathrm{Y}_{\text {computed }}$ are observed and computed values of considered parameter, respectively, and $\mathrm{N}$ is number of parameters. Optimum values of equation coefficients, for various forms of $F_{0} /\left(\mathrm{H}_{\mathrm{C}} / \mathrm{R}_{\mathrm{H}}\right)$ exponent, as an example for scour-hole length, is shown in table 3. 
Table 3. Coefficients of equation (6) and rate of error percent for various forms of $F_{0} /\left(H_{c} / R_{H}\right)$ exponent (scour-hole length)

\begin{tabular}{c|c|c|c|c|c|c}
\hline $\begin{array}{c}\text { Exponent } \\
\text { form }\end{array}$ & $\mathbf{a}$ & $\mathbf{b}$ & $\mathbf{c}$ & $\mathbf{d}$ & $\mathbf{R}^{2}$ & $\mathbf{E} \%$ \\
\hline $\mathbf{c}$ & 3.981 & 0.098 & 0.892 & - & 0.913 & 11.404 \\
\hline $\mathbf{c}\left(\mathbf{T}_{\mathbf{w}} / \mathbf{R}_{\mathrm{H}}\right)$ & 0.124 & 1.336 & 0.051 & - & 0.842 & 15.433 \\
\hline$\left(\mathbf{T}_{\mathbf{w}} / \mathbf{R}_{\mathrm{H}}\right)^{\mathbf{c}}$ & 4.736 & 0.028 & -0.046 & - & 0.915 & 12.304 \\
\hline $\mathbf{c}\left(\mathrm{T}_{\mathbf{w}} / \mathbf{R}_{\mathrm{H}}\right)^{\mathrm{d}}$ & 26.992 & -0.626 & 3.015 & -0.468 & 0.923 & 9.959 \\
\hline
\end{tabular}

It is observed that when the exponent form is $\mathrm{c}\left(\mathrm{T}_{\mathrm{w}} / \mathrm{R}_{\mathrm{H}}\right)^{\mathrm{d}}$, the error term will be minimized. Similar tables were developed for other scour-hole and its downstream sediments mound characteristics. A general form of the scour characteristics prediction equation is as follows:

$$
\frac{\Psi}{H_{c}}=a\left(\frac{T_{w}}{R_{H}}\right)^{b}\left(\frac{F_{0}}{H_{c} / R_{H}}\right)^{c\left(T_{n} / R_{H}\right)^{d}}
$$

Optimum values of the equation coefficients for other scour characteristics, is shown in table 4. In figure 6, a plot of the observed scour-hole length with respect to the computed values is shown. Similar plots were developed for other scour-hole and its downstream sediments mound characteristics. It is observed that the computed values of scour-hole length have the least variance with observed values.

Table 4. Summery of coefficients and error percent of estimation equation of other scour characteristics

\begin{tabular}{c|c|c|c|c|c|c}
\hline $\begin{array}{c}\text { Scour } \\
\text { characteristics }\end{array}$ & $\mathbf{a}$ & $\mathbf{b}$ & $\mathbf{c}$ & $\mathbf{d}$ & $\mathbf{R}^{2}$ & $\mathbf{E} \%$ \\
\hline $\mathbf{d}_{\mathbf{s}}$ & 154.261 & -1.791 & 21.937 & -1.254 & 0.931 & 11.044 \\
\hline $\mathbf{W}_{\mathbf{s}}$ & 103.816 & -1.248 & 8.255 & -0.929 & 0.902 & 11.233 \\
\hline $\mathbf{h}_{\mathbf{m}}$ & 2.992 & -0.322 & 3.903 & -0.508 & 0.962 & 6.863 \\
\hline $\mathbf{L}_{\mathbf{r}}$ & 113.849 & -1.322 & 11.378 & -1.016 & 0.905 & 10.8 \\
\hline $\mathbf{L}_{\text {up }}$ & 0.501 & 0.358 & 0.278 & 0.211 & 0.856 & 7.996 \\
\hline
\end{tabular}

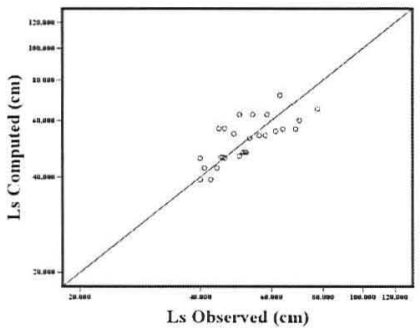

Figure 6. Comparison between observed and computed values of scour length 


\section{CONCLUSION}

This experimental study investigated the effect of tailwater depth on the characteristics of local scour at downstream of falling jets. The following conclusions are derived:

1. The characteristics of scour-hole and its downstream sediments mound depend on erosion parameter, $\mathrm{F}_{0} /\left(\mathrm{H}_{\mathrm{c}} / \mathrm{R}_{\mathrm{H}}\right)$, and tailwater parameter, $\mathrm{T}_{\mathrm{w}} / \mathrm{R}_{\mathrm{H}}$.

2. The tailwater depth has significant influence on sediments mound height. In lower tailwater depths, sediments will settle in uniform state (with a constant height) at downstream of scour-hole, but in higher tailwater depths, the settled sediments form a climax which has steep slopes at upstream and downstream.

3. The tailwater depth changes have double influences on scour characteristics. Increasing the tailwater depth from $6 \mathrm{~cm}$ to $12 \mathrm{~cm}$ causes increasing the depth, width and length of scour-hole and so the length of sediments mound on the average of 104, 42, 39 and $83 \%$, respectively. But increasing the tailwater depth from $12 \mathrm{~cm}$ to $18 \mathrm{~cm}$ causes decreasing these characteristics on the average of $23,24,18$ and $16 \%$, respectively.

4. Generally, the increasing of tailwater depth from $6 \mathrm{~cm}$ to $12 \mathrm{~cm}$ and then to $18 \mathrm{~cm}$, causes increasing sediments mound height on the average of $52 \%$.

5. A general form of the scour characteristics prediction equation for all tailwater ratios is as follows:

$$
\frac{\Psi}{H_{c}}=a\left(\frac{T_{w}}{R_{H}}\right)^{b}\left(\frac{F_{0}}{H_{c} / R_{H}}\right)^{c\left(T_{w} / R_{H}\right)^{d}}
$$

It is observed that the computed values by this equation have the least variance with observed values.

\section{REFRENCES}

Abida, H., Townsend, R. D., (1991). "Local scour downstream of box-culvert outlets", Journal of irrigation and drainage Engineering, Vol. 117, No. 3, P.P. 425-440

Ghodsian, M., Melville, B., Coleman, S., (2006). "Scour caused by rectangular impinging jet in cohesiveless beds", Proc. Third International Conference on scour and erosion, ICSE, Nov. 1-3, Amsterdam, The Netherlands

Najafi, j., Ghodsian, M., (2004). "Experimental Study of scour hole properties at downstream of pipe culvert", Technical faculty, Tehran University, Tehran, Iran, Journal No. 84, P.P. 329-338

Nasehi, M., (1996). "Scour profile at downstream of vertical drops", Proceeding of the $4^{\text {th }}$ international River engineering conference, Shahid chamran University, Ahvaz, Iran, P.P. 474-488

Sarathi, P., Faruque, M.A.A., Balachandar, R., (2005). "Local scour by three-dimensional wall jets", Proc. $17^{\text {th }}$ Canadian Hydrotechnical Conference, CSCE, August 17-19, P.P. 647-654, Edmonton, Alberta 